\title{
Integrating Cloud World Synergy in ELT to Adults: Perspectives of Handheld Technologies
}

\author{
https://doi.org/10.3991/ijim.v13i10.10783 \\ Mohammed Abdulgalil Abugohar ${ }^{(凶)}$, Kamariah Yunus \\ Universiti Sultan Zainal Abidin (UniSZA), Kuala Terengganu, Malaysia \\ modyjaulyahoo.com \\ Ghaleb Rabab'ah \\ University of Jordan, Amman, Jordan \\ Tarig Awad Eltahir Ahmed \\ Alzaiem Alazhari University, Khartoum, Sudan
}

\begin{abstract}
The outcomes of modern technology have turned real-world interaction into a virtual community, then into a cloud one. These giant leaps aided by the excitement created by the possibilities inherent in learning through handheld technologies made using mobile devices in English language teaching (ELT) indispensable. This paper is aimed to deeply overview available handheld technologies and their features that can enable teachers in their mission. It investigates the synergy of a group of mobile devices of smartphones, tablets, iPods, iPads, E-readers, and classroom response systems, among others. These devices have been effective in everyday activities, and are expected to enrich ELT, especially in communities where there is a lack of community of practice (CoP) on the target language. To this aim, this paper was cored around reviewing the potential handheld technologies have in language classrooms. The main data were obtained from the rich body of literature, shedding more light on their properties in creating interactive communication in and out of classrooms. The findings revealed that handheld technologies can be successfully integrated into English language teaching and learning. Pedagogically, teachers are encouraged to exploit mobile devices into their classroom practices after closely testing their specifications, and scanning their advantages and shortcomings.
\end{abstract}

Keywords - Cloud World Synergy; English Language Teaching (ELT); Adult learners; Integrating; Mobile Devices; Perspectives; Handheld Technologies.

\section{Introduction}

The vast development of the digital world, as evident in portable electronic devices, has generated new trends in every facet of modern life [1], and has become an integral part for all people, mainly for youths. Learners at university levels use a variety of tools to store, recall and browse a huge repertoire of information, and keep updated with modern technology. Mobile devices such as personal digital assistants (PDAs), iPads, 
laptops, E-readers, and smartphones have brought a paradigm shift in education [2; 3 ; 4]. Due to modern technology, ELT has witnessed giant leaps in classroom practices during which the educational process has been centred on students' actual performance as the target outcome. This explains the reason for uncovering the potential of modern technology in ELT [5; 6; 7].

Yet, when adult learners step inside their schools, they are shocked by a sign saying 'No mobile devices are allowed in'. They are obliged to either leave their electronics at home or at least switch them off during classes. A widely-shared sentiment among educators is that mobile devices in the classroom function as a serious distraction, scattering students' attention away from the on-going instruction [8; 9]. This kind of banning of mobile devices in the classroom has led to more serious issues of using these devices secretly in a way that widens the gap between what teachers deliver and the way students like to learn through, neglecting the rich resources mobile devices have in the educational process. In terms of modern technology, EFL/ESL teaching is still a step behind.

This paper discusses the potential of handheld devices in English language classrooms, with the foci on integrating multimodal language instruction involving the use of images, audios and videos, and facilitating authentic materials over the Internet for adult students to practise in and out-of-classroom.

\subsection{Research Significance}

Implementing mobile learning technologies in adult teaching context is still in its infancy, and the development of new models and applications are needed to be put in action for successful integration [10;11]. Teachers need to re-blend the current learning environment at universities to cope with the current rapidly changing digital era. One of these reform attempts is to effectively use handheld technologies in ELT. This important aspect is what gives the present paper its significance. The rationale behind this study is that educationalists and practitioners urgently need to understand and acknowledge the changes in today's learner's attitudes towards learning; and thus, they can design learning which switch from conventional practices to tech-based content in order to meet students' needs and fit their modern trends; among those practitioners, English language teachers are no exception.

\section{Reviewing Literature}

Literature is rich in various studies that concentrated on utilizing handhelds in learning in general, and in language learning in particular. Published research on mobile use in education has mainly concluded that the use of portable electronics is dramatically increasing in schools and universities. The findings of [12] showed that the meta-analysis of mobile devices usage has been widely spread in a variety of subjects, with science, literacy and language coming first respectively. Also, they found that $70 \%$ of the studies done on handheld technologies resulted in positive outcomes. 
In support of the previous findings, [13] reviewed previous studies on the use of handheld devices in higher education revealing overall positive results. They concluded that science, languages, and professional training were most often the subjects of published studies. In addition, the most frequent use of mobile tools was for multimedia access. However, few papers focused on collaborative or communicative uses.

In addition, [14] could successfully provide 'snapshots' concerning learners' experiences and attitudes towards the use of BlackBerry ${ }^{\mathrm{TM}}$ as a new teaching and learning device for adult learners in a higher-education, graduate-level business program. Moreover, [15] shed light on the positive impact of using smartphones in bridging the gap of the still existing digital divide. Smartphones can serve as the most convenient medium to connect to the Internet. This allows learners to have access to information and easily communicate with others, yielding into a better classroom.

Further, [16] found out a significant influence on learning with mobile devices than with desktop technology or without technology at all. On the contrary, [17] conducted a study on 31 Canadian university students who were issued tablet PCs for their use during an academic year, concluding that little evidence was found to support a contention that meaningful learning with technology had occurred and, in spite of their comfort and familiarity with the technology, there is no evidence of changing attitudes with respect to meaningful learning on the part of the students surveyed in their study.

Plus, in their paper [18] examined the impact of using smartphones on both secondary and post-secondary students, revealing their positive effect on pedagogy and student comprehension. Finally, [19] could draw the attention of Arab EFL teachers to the potential smartphones have in language teaching and learning through investigating teachers' perceptions and practices of implementing smartphone software in helping university students promote their oral skills.

\section{$3 \quad$ Research Methodology}

This is a review paper in which the available literature is deeply investigated to shed light on mobile devices and their features. First, authors googled reputable platforms such as Eric, ResearchGate, DOAJ, and the British Library EThOS, among others, for available papers, studies, and theses concerning handheld technologies and mobile devices. Then, some inclusion criteria were developed to limit the scope. Inclusion criteria dwell in the fact that articles that link handhelds with language teaching and learning are the ones to discuss. The proposed debate is proceeded according to a group of questions. Answering these questions yields a full understanding of mobile devices perspectives. The following sections aim to deeply overview handhelds that can be utilized in ELT to adult learners by finding answers to four main questions set to guide this work as follows:

RQ1: What are the various types of handheld technologies?

RQ2: What is the potential of mediating handheld technologies in ELT?

RQ3: In which context can mobile devices be implemented?

RQ4: Which techniques to follow in using handheld technologies in ELT? 


\section{$4 \quad$ Handheld Technologies}

In this section, answers are sought to the first question of this paper. First, the history of introducing handheld technologies is briefed. Then, various types of mobile devices are presented along with discussing their general properties.

\subsection{History of Mobile Devices}

Mobile devices range from tiny gadgets to average-size electronics. Brand new brands, modified versions, different sizes, enhanced capabilities, and various types are introduced on a daily basis. [18] trace the history of on-the-go or mobile communication stating that this kind has been promoted for decades with the aim to have telephone call transactions while in transit. According to [18], the first hand-held mobile phone was demonstrated in 1973 by John F. Mitchell and Dr. Martin Cooper of Motorola with a handset weighing around 2.2 pounds. Henceforth, 'April 3, 1973' was seen as the official release of the cell phone. Then, time passed bringing further advancements $[20 ; 21$; $22 ; 23$ ] as in Table 1.

Table 1. Historical Timeline of Mobile Devices

\begin{tabular}{|c|c|c|}
\hline Device & Year & Comments \\
\hline Newton Message Pad & 1993 & First PDA on the market \\
\hline Palm Computing & 1996 & First commercially successful PDA \\
\hline Microsoft Tablet PC & 2001 & First tablet on the market \\
\hline Apple iPod & 2001 & First commercially successful MP3 Player \\
\hline Apple iPhone & 2007 & First smartphone from Apple-iOS released \\
\hline Apple iPod Touch & 2007 & First non-phone PDA from Apple \\
\hline Amazon Kindle & 2007 & First commercially successful eBook reader \\
\hline Google Android OS & 2008 & First serious competitor to Apple iOS \\
\hline Apple iPad & 2010 & First commercially successful tablet computer \\
\hline Apple iPad Mini & 2012 & First small tablet computer from Apple \\
\hline
\end{tabular}

Due to the astonishing changes and new trends in mobile technologies, a wide range of devices has been introduced, and all of them have the properties that make them valid as teaching and learning aids in language classrooms, making learning in general, and English language (EL) in particular, more attractive and much more effective.

\subsection{Types of Handheld Technologies}

Reviewing literature, various inconsistent definitions were found for handheld technologies due to the lack of a uniform definition and because of the angle from which researchers look at mobile devices. Some give general technological definitions while others provide operational concepts, linking technologies with education. A handheld device can be generally defined as a small computer-based mobile that has a touch display or a small keyboard as an input unit. A similar definition given by [4] is that 
handhelds are small, mobile devices that are considered "on-the-go" computers. A third classifying definition asserts that mobile phones, smartphones, tablet computers, eBook readers, personal digital assistants (PDAs), and other similar devices can all be categorized as mobile devices [24]. An instrumental definition states that mobile learning is the intersection between mobile computing (the application of small, portable and wireless computing and communication devices) and e-learning (learning facilitated and supported through the use of information and communications technology [25]. Thus, mobile-assisted language learning (MALL) is defined as learning occurring with the help of mobile devices [26; 27; 28]. Finally, [29] defines mobile-learning as "learning across multiple contexts, through social and content interactions, using personal electronic devices" (p.4). Some of the introduced devices are shown in Figure 1.

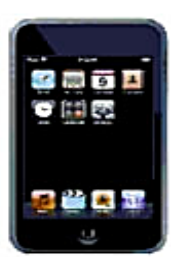

iPod Tovch

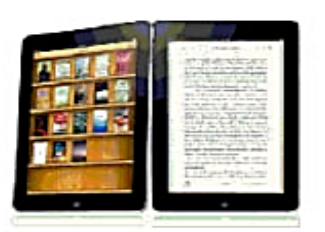

IPad
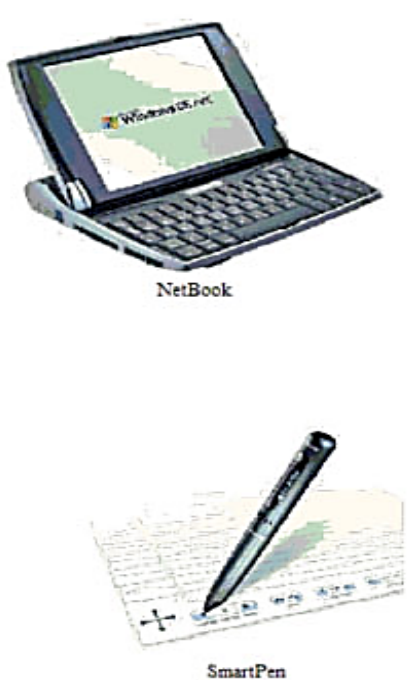
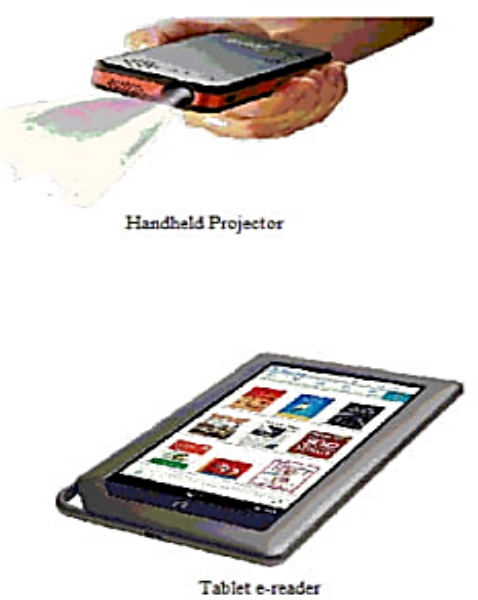
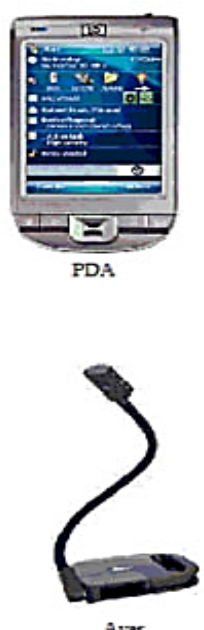

Aver

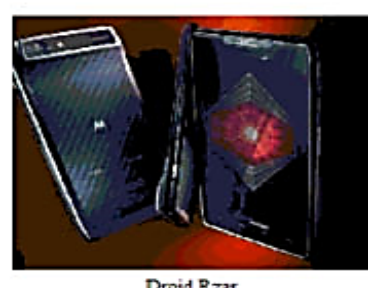

Droid Rzar

[4]

Smartphones. With the advent of mobile phones that have been recently turned into smartphones, a giant rise in popularity and technological advancement has resulted in developing mobile education [30; 31], enabling adult learners to not only download and use educational applications, but also going beyond by offering the opportunity for students to develop their own users' interface and applications (Apps) [19; 32; 33]. 
Smartphones can also facilitate digital interaction between students, parents, and teachers. Students are able to access digital files, collaborate online and use the internet anywhere. Whether educational institutions agree or decline, smartphones used in learning are here to stay. Gradually, smartphones are becoming commonplace as instructional instruments. No matter the subject is, ELT should consider utilizing smartphones in language classrooms.

Tablets. Tablets are a great addition to the ever-expanding family of computer-like devices [34]. Tablets are small portable computers, which are worldwide labelled as the future exciting channels of learning, replacing traditional classroom settings of textbooks and pens. Mobile tablets offer benefits such as seemingly boundless access to information and advantages for collaborative learning. Many experts still believe that the pros far outweigh the cons when it comes to general tablet use in education. With tablets, ESL/EFL learners are no longer frustrated. They can learn the interesting way via tables' software; not by chalk-and-talk methods. Instead of resisting, EL teachers should realize that fact and make use of these devices.

iPads. The iPad was introduced into education in 2010 [76]. In language classrooms, iPads are rich in resources to facilitate learning and engage students interactively [6]. Using iPads, learners can access the Internet, take notes, access calendars, and reference materials, word process and read books, magazines and other print materials, and access thousands of apps to support a wide variety of learning outcomes [35; 77]. iPads are not only for games; teachers can also use iPads and the multitude of apps to support the curriculum, aid in assessment and to create interactive lessons; even games can be informative and thought-provoking for students fostering their higher thinking abilities of creativity and critical thinking. However, it should be guided by set of criteria [76].

Classroom Response Systems. Classroom or student response systems (clickers) have increasingly become in demand for interactive classroom instruction [36]. This kind of technology allows users to anonymously, or within a software classroom grade book, respond to a question/questions that is/are posted. This type of technology is expected to enhance collaboration among language learners. This technology actively encourages learners to participate in class and express their understanding of the target material due to the anonymity of the system [37], especially in a setting where students feel demotivated due to their poor performance and high level of anxiety. It seems as if a student were talking to a device, not to a human being; this can lessen the stress factor some EFL learners feel when interacting in a second language (L2).

E-readers. E-readers (also known as e-book readers or e-book devices) allow students to access books, textbooks, magazines, and other texts electronically, and to store them in one place. Some believe that the use of e-readers to access classroom text materials may replace traditional paper textbooks altogether. E-readers can sometimes be a lifesaver for those who suffer from reading difficulties such as dyslexia [38]. E-readers also have tremendous potential to entice reluctant readers and to encourage language learners to read more and more.

Handheld Devices and the Internet . Regarding the Internet, it has dramatically changed the handheld technology market. By the end of 2018, the number of mobile subscriptions has risen to almost 7.75 billion, and the number of devices connected to the Internet by 2020 is projected to reach 50 billion [39]. [40] reported that smartphone 
numbers overtook PCs clients in 2011. By 2020, it is predicted that digital technology will be dominating all fields. Personal artifacts such as keys, clothes, shoes, notebooks, and newspapers will have devices embedded within them, which can communicate with each other [41]. This dominance has provided educators the opportunity to deliver meaningful learning via mobile devices. But why do not EFL teachers do the same?

\section{Handheld Technologies \& ELT}

This section is meant to answer the second question for this article 'What is the potential of mediating handheld technologies in ELT?' This is accomplished through four steps. First, light is shed on some software and applications used in ELT. Second, merits of utilizing handheld technologies in ELT is explored. Third, the drawbacks and barriers to using such devices are addressed. Finally, potential of mobile devices in ELT is discussed.

\subsection{Available Software and Applications}

Based on $[42 ; 43 ; 44 ; 11 ; 45]$ and $[46]$, apps come in one of three main categoriesnative apps; having operating systems, web/cloud apps; cloud/web-based, or hybrid; combining both previous characteristics. Prior to discussing various types of applications available for EL teachers to use in language classrooms, specific requirements should be set first. [47] asserts on two main requisites for adopting new technology within formal educational systems. These requirements are that educationalists should first validate the pedagogical effective role of technology and view it as an improvement. Second, they have to check both the availability and accessibility of modern technology to all the involved in the teaching/learning process.

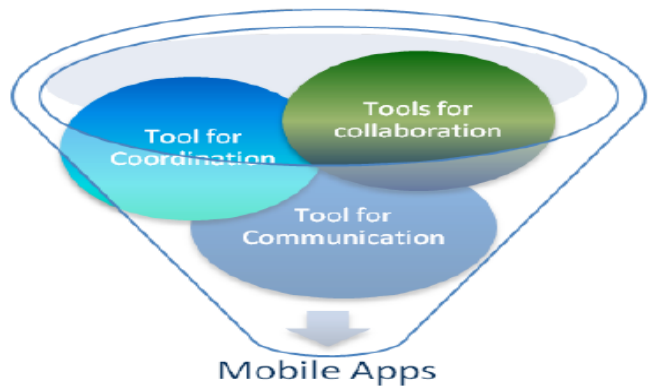

Fig. 2. Tools for Handhelds [10]

As shown in Figure 2, [10] mention three forms of handheld tools used in the education process as follows:

1. Apps as tools for Collaboration and interaction (such as Google Play Apps, and App Store Apps) can be used for sharing documents and files. 
2. Apps as tools for Coordination and instruction (such as Twitter, Edmodo, Kahoot) and can be used to inform students about assignments due date and class organization.

3. Apps as tools for telecommunications (such as Skype, Facebook, WhatsApp, IMO) and can be used for synchronous and asynchronous communication, discussion and sharing among students.

On the other hand, [19] categorize smartphone applications into three- audio-based, video-based, and speech recognition. Moreover, [48] update the apps graph in Figure 2 to demonstrate a variety of tasks in formal and informal settings as depicted in Figure 3 .

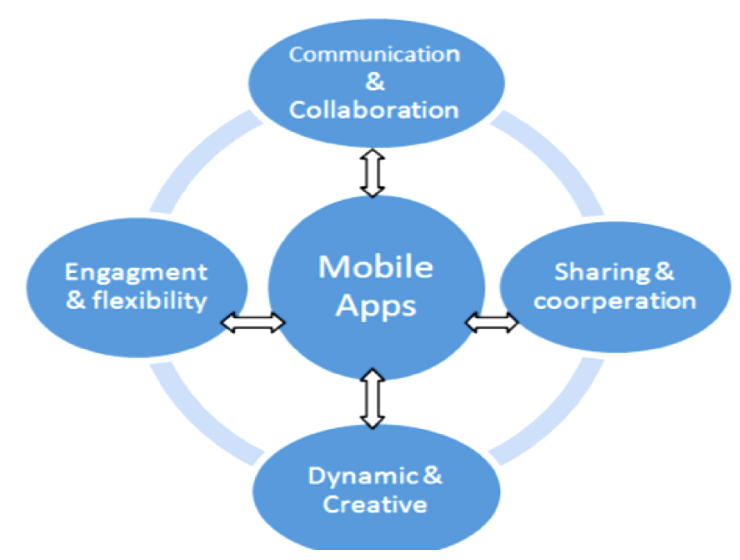

Fig. 3. Skills Learned via Mobile Apps [48]

\subsection{Advantages of Mediating Handheld Technologies in ELT}

There are a lot of positive aspects or pros of using handheld computers in and out classrooms. In language classrooms, all can take their own notes electronically, then forward the information to one tablet to compile. This can be a huge help in ELT practices through various available applications, and may be helpful in EFL/ESL classes [76] with word/speech recognition systems (SRS) to assist learners with unfamiliar vocabulary, replacing paper-and-pen activities. Assessment results can be downloaded to the mobile device or a set website and made accessible to parents. In case of missing a class, students can download or watch the lecture online using such tools or technologies. In this way, paperwork can be drastically eliminated, and school activities become paperless.

[49] counts for a group of merits resulting from implementing mobile devices in language learning. [49] advocates that such tools make the learning environments more attractive, provide both faculty staff and learners with ubiquitous access to rich repositories, and cut costs and save money since they no longer need wires, cables, much more space or heavy hardware, in addition to maximizing the access to standardization of platforms, and minimizing the need for technical support. 
There are some more good points of using handheld technologies, such as the powerful ability and flexibility of multimedia, the easiness of logging on to the Internet where students can get answers to complicated problems within seconds, the variety in social networking, and the immediate feedback English language learners can get directly. Nonetheless, while teachers and students, on one hand, are very positive about handheld technologies; there are several obstacles faced on the other hand.

\subsection{Disadvantages and Setbacks}

On the other hand, mobile devices may be very distracting for some students. Multitasking lowers language learners' own productivity while simultaneously distracting other students. Restrictive measures to limit distraction can also be problematic, promoting a "Teacher vs. Technology" mentality that students will not respond well to [4]. Some teachers' practices of selecting apps haphazardly is another drawback [78]. Cameras on handhelds can involve privacy issues. And plagiarism acts are some of these issues. In brief, using handheld computers in and out of classrooms may result in some disadvantages (cons) if not applied effectively. These demerits are centred on three main points of distraction, cheating, disconnection, and technical issues.

In terms of barriers, there are technological constraints which hamper adapting the right mobile Apps for teaching and learning due to the high variation found among handheld devices from hi-tech smart devices to the low-tech ordinary mobile device. This makes applying one-size fits all a complex challenge in university settings [50; 25]. Another major issue is the reusability of content on different devices. Plus being time-consuming, these devices costs, especially in low-income countries, are among other barriers. Sometimes, it is impossible for lecturers to create content for all different platforms separately. Moreover, technical issues such as difficulty connecting to the Internet, hardware failures and software issues are all common problems. Another shocking barrier, which is supposed to be an advantage, is the very richness of options available today on mobile devices. While the ever-growing set of tools, services, and apps may be empowering to students, it may seem overwhelming to teachers looking to start using mobile devices in their classes [51].

\subsection{Potential of Mobile Devices in ELT}

Indeed, smart technology plays a very significant role in our daily practices; while in learning settings its implementation is not at the same foot with that of non-educating activities. Thus, this section attempts to zoom in the potential these technologies have in the education sector.

Handheld technologies have introduced a new generation of educational tools that placed importance on creative use and instant access to a wealth of resources. These devices hold promising potential for language learning. Such tools through a variety of resources can accommodate each student's natural and preferred learning style, stretching beyond their comfort level, and pulling learners' legs to try out different approaches to learning. 
Integrating mobile Apps and technologies within the teaching and learning environment holds many benefits to the university language learning context since using such tools is fast, easy, convenient, efficient, and can facilitate accurate access to various learning corpus or content. Among other properties are the portability, flexibility, and availability of the learning content. When a learning content is saved on the mobile device, it can be transferred, shared and copied. Materials over these devices can be used as a supplement to the traditional and/or online learning presentations. They are further applied as communication channels, offering teachers and students a sharing collaborative learning environment. They act as note-padding for taking topic notes whenever users need, without being attached to a wired computer.

In addition, mobile learning technologies well foster and aid 21st century language skills as stated by Partnership for 21st century learning [52] in Figure 4.

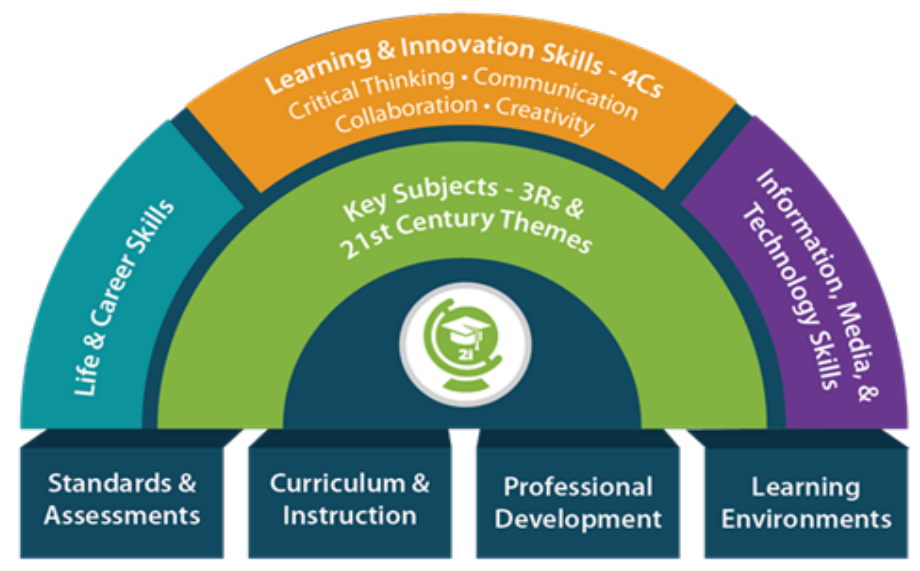

Fig. 4. Framework for 21st Century Learning [52]

Another reason that lies behind using handheld technologies is that these portable devices help maintain a sound environment where learners can interactively express themselves, exploiting the Internet and modern technology as stressed by [1] and [7], whether within the course realm or using extracurricular activities to enrich language teaching and learning [53]. These handhelds maintain the $4 \mathrm{Cs}$ of the 21 st century language skills of communication, collaboration, critical thinking, and creativity $[4 ; 52]$. This can promote the oral production issues that were deemed crucial and problematic for language learners as concluded by [54].

[55] advocate that the potential for learning with mobile technology has been equated with " 21 st century learning skills". Although multiple components constitute 21 st century learning skills, many frameworks identify creativity, collaboration, coconstruction of knowledge, and an inquiry approach to learning [56] as key or critical components. Mobile technologies also provide the opportunity for students to develop self-regulated learning skills [57; 58; 59]. 
[60] attempted to foresee the future of convergence network in bringing about onthe-run learning beyond limits. For universities, it may be beneficial to support the existing teaching methods with an M-learning infrastructure that enriches learning anytime and anywhere. Their predictions are illustrated in Figure 5. However, to these two authors, it can be said that it has become much more advanced than you foresaw.

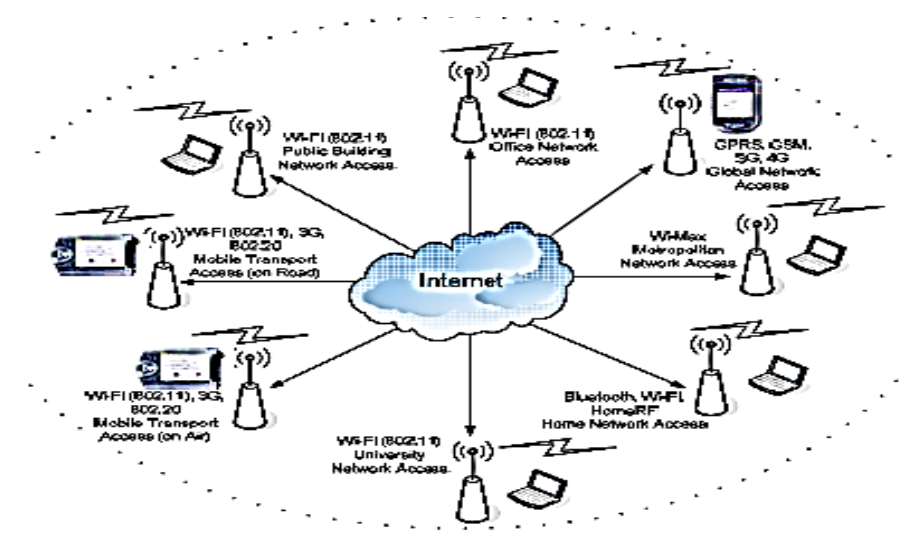

Fig. 5. The Future Convergence Mobile Learning Network [61]

\section{Context of Handheld Technologies in ELT}

The increasing popularity of handheld devices is dramatically hastening. This fact could be elicited from the huge number of studies found attempting to explore, investigate, and experiment the influence of mobile technologies on learners' performance. These portable devices emerged as a new generation of digital tools that grant users endless access properties to various contents as well as opportunities for creative use in a way that is undoubtedly appealing to all learners at any age. In this section, RQ3 regarding the context is answered in three sub-sections. The first is about 'Which' skills to target; the second is to specify the (Who?) or the population with whom handheld technologies are used; while the third is concerned about settings of 'Where' and 'When', or place and time constraints in the field of utilizing educational mobile technologies.

\subsection{Target Skills}

Handheld technologies provide unavoidable support in education and help students develop new important skills [62]. All four language skills are addressed by using mobile devices, as well as cultural learning. This is due to the rich resources available across different mobile functions, apps, and web-based resources [8]. In language classrooms, it has been deemed that mobile devices, with appropriate software, can effectively elevate the quality of learning outcomes. 
Mobile devices software and applications address a variety of language skills due to their flexibility and versatility in their use in language learning. Listening, speaking, reading, writing, vocabulary, and grammar, among others can be enhanced across handhelds, facilitating authentic resources and effective materials attractively.

\subsection{Target Learners}

The integration of digital technology has been stressed by many studies to be integrated at all education levels, even at the primary stage with kids [62]. Surprisingly, there have been more studies on using handheld devices in elementary schools than in high schools. Most studies came from Asia, with Taiwan contributing the largest number of articles [18]. With the constant emergence of new technological advancements, more application opportunities are facilitated for the educational process fitting all learners' needs at all stages. However, this paper has selected university students and their ESL/EFL instructors as the population addressed by this discussion since learners at this stage are expected to be more qualified, and more experienced in using complicated mobile tools and advanced software, and for adults, such devices are more affordable than other age groups.

\subsection{Settings (Location \& Time)}

Regardless of the vast use of mobile technologies for social purposes, handheld devices have many implications for educational purposes. Using such tools ensures fostering the learning process in language classrooms and beyond the walls of schools.

[55] interestingly concluded that the two different educational and technological contexts also highlighted unique outcomes. They stressed on the vital role played by handheld devices outside language classrooms in no less than inside classrooms. According to [55], for adult language students specifically, the BlackBerry ${ }^{\mathrm{TM}}$ mainly served as a tool for communication and collaboration outside classrooms, whilst implementing the iPod was significantly more effective within classroom practices with limited use beyond classrooms.

Language learners can use this kind of devices whenever, wherever they wish. Employing mobile devices in ELT comes in handy and facilitates teaching and learning English skills in and out of classrooms at any time. Integrating handheld technologies within ESL/EFL settings makes learning more relevant, interesting, and get students engaged more in the process of acquiring or learning a language in any context and at any time. Portable/Mobile learning (M-learning) is instrumental; it can accommodate and support a learner whatever his context is $[63 ; 11 ; 64]$.

\section{Techniques of Implementing Handhelds in ELT}

Language learning in this 21st digital Century is omnipresent with technology and getting more and more momentous in every single corner of youths' lives. These 
changes have resulted in a rethinking of teaching and learning methods in the new digitalized environment at all educational levels [65]. Thus, making use of mobile technologies in second/foreign languages teaching and learning is a must. It is through a 3stage process, applying mobile devices and their software can be more effective in ELT to adult learners. EL teachers can follow the process of 'inspire', 'empower', and 'achieve' for helping their students master language skills using high-tech tools.

A major potential of mobile devices for learning lies in the ability to provide timely access to learning in authentic working contexts $[66 ; 67 ; 11]$, bridging the gap between formal and informal learning [11].

Nonetheless, implementing such aids demands getting appropriate training for both EFL/ESL teachers as well as learners on the effective use of these handhelds in language classrooms. Plus, users must be introduced to the traits of the applications applied and how to log on them, whether they need prior registration or ready to use at the first login, available for free or require premium accounts. All that EL teachers need is informed by recognizing the possibilities available within their own curriculum, teaching pedagogy and students' learning style, and identifying the types of the target activities with hands-on. Then, they can implement these devices accordingly. Being drilled on using such instruments enables both teachers and learners to use these devices and their software properly and appropriately in a way that maintains an efficient educational continuum. The above discussion is considered as an answer to RQ4 for this research.

\section{Discussion}

By answering the main four questions set to guide this paper, it has become clearly evident that the 21st century students are not restricted to obtaining the knowledge of life, even in the classroom setting, where there are now various aspects of modern technology. The face of the contemporary classroom is ever-changing, and this change requires innovation in the educational process. Handheld technologies have pervasive properties that can control modern era [55]. ELT using such tools has the potential to be significant and even revolutionary in ESL/EFL effective pedagogy, providing better learning opportunities, and aligning teaching practices with the real-life stream by allowing students to use their devices as learning aids in a way that breaks down the barriers between scholastic environment and real life, in which mobile technology is integrated into most spheres of work and leisure. Recently, handheld devices have become so ubiquitous that adult learners are likely to expect to use them as part of their university lives $[8 ; 68]$.

The mobile revolution is here to stay. More and more educational institutions are stepping ahead to applying mobile technologies in the classroom as a way to take advantage of the new wave of electronic devices that offer portability and easiness of use on a budget. Such technologies capture students' attention and enhance their learning process. Future holds more and more ambitious features for such technologies.

Despite this potential and these promising features, why is it that most language teachers are reluctant to introduce their use in the classroom? It is more than the excuse of avoiding the distraction factor that may result from using handheld technologies. 
Evidently, EL teachers tend to teach the way they were taught, which for the current generation of teachers had not included the use of mobile devices $[69 ; 11 ; 70]$.

Utilizing handhelds in ELT to adults require a very structured format for students to follow. Mobile devices can be used for reinforcing language learning objectives for students and as an instructional aid for teachers, providing rich and authentic resources for language practices inside and outside the classroom. Therefore, students need to get a clear and concise vision of how to use mobile devices for educational purposes.

In summary, language learners are more curious about what makes them more engaged in the learning process, promotes their autonomy and self-esteem, and enriches ELT in and out of language classes. Adult learners are no longer in favor of the traditional method of the mere verbal lecture. Consequently, educators must be aware of the way these handhelds and their applications are applied to reach all learning styles.

\section{Conclusions}

Over the past few years, there has been a new trend in the educational system that invests more in information and communication technology in the teaching-learning process. Mobile learning using portable devices to access and share information is a trend in higher education, redefining how language learning takes place and how instruction should be delivered $[71 ; 72 ; 73]$. Mobile learning technologies offer teachers and students a more flexible and interactive approach to interact within for the purpose of active learning. In this context, handheld technologies, including smartphones and tablets emerge as innovative tools associated with ELT to university students [71; 72; 4], supplementing language learning anywhere at any time [74].

Conclusions drawn show that the advantages of mobile devices implemented in ELT overshadow some barriers and challenges at the same time. Educators must stay abreast of this modernization and how to incorporate handheld technologies into their pedagogy, taking into consideration that mobile technologies do not ensure achieving ELT objectives by themselves. Proper directions and supervisions are in great demand to satisfy the success of language learning and teaching.

What is evident is that with proper training to teachers and students, supervision of students and the awareness of mobile learning; educational systems will soon be able to make rapid strides [75]. Further studies are recommended to experimentally examine whether the application of handhelds in ELT has a practical, positive impact on EL learners' academic performance in different language skills.

\section{References}

[1] Che Had, M. Z., \& Rashid, R.A. (2019). A review of digital skills of Malaysian English language teachers. International Journal of Emerging Technologies, 14(2), 139-145. https://doi.org/10.3991/ijet.v14i02.8732

[2] Daughtery, C., \& Berge, Z. L. (2017). Mobile Learning Pedagogy. International Journal for the Scholarship of Technology Enhanced Learning, 1(2), 11-118. 
[3] Johnson, L., Levine, A., Smith, R., \& Stone, S. (2010). The 2010 horizon report. Austin, TX: New Media Consortium.

[4] Ochola, J.E., Stachowiak, J.R., Achrazoglou, J., \& David B. (2013). Learning environments and rapidly evolving handheld technologies. First Monday, 18(4). https://doi.org/10.5210/fm.v18i4.3932

[5] Abugohar, M. A., \& Yunus, K. (2018). Difficulties encountered by Arab students in pronouncing English correctly. International Journal of Education \& Literacy Studies, 6(4), 93100. https://doi.org/10.7575/aiac.ijels.v.6n.4p.93

[6] Elyas, T., \& Al-Bogami, B. (2019). The role of the iPad as instructional tool in optimizing young learners' achievement in EFL classes in the Saudi context. Arab World English Journal, [Special Issue], February 2019, 144-162.

[7] Rashid, R., Mohammed, S., Rahman, M., \& Shamsuddin, S. (2017). Developing speaking skills using Virtual Speaking Buddy. International Journal of Emerging Technologies in Learning, 12(5), 195-201. https://doi.org/10.3991/ijet.v12i05.6955

[8] Godwin-Jones, R. (2018). Using mobile devices in the language classroom: Part of the Cambridge papers in ELT series. [pdf]. Cambridge: Cambridge University Press. Available at cambridge.org/betterlearning

[9] O'Bannon, B. W., \& Thomas, K. (2014). Teacher perceptions of using mobile phones in the classroom: Age matters! Computers \& Education, 74, 15-25.

[10] Khaddage, F., Lattemann, C., \& Bray, E. (2011). Mobile apps integration for teaching and learning: Are teachers ready to re-blend? In M. Koehler \& P. Mishra (Eds.), Proceedings of SITE 2011- Society for Information Technology \& Teacher Education International Conference (pp. 2545-2552). Nashville, Tennessee, USA: AACE). Retrieved from https://www.learntechlib.org/primary/p/36694/

[11] Khaddage, F., Müller, W., \& Flintoff, K. (2016). Advancing mobile learning in formal and informal settings via mobile app technology: Where to from here, and how? Educational Technology \& Society, 19(3), 16-26.

[12] Crompton, H., Burke, D., \& Gregory, K. H. (2017) The use of mobile learning in PK-12 education. Computers \& Education, 110(C),51-63. Doi:10.1016/j.compedu.2017.03.013

[13] Al Zahrani, H., \& Laxman, K. (2015). A Critical Meta-Analysis of Mobile Learning Research in Higher Education. The Journal of Technology Studies, 41(2), 74-89.

[14] Wood, E., Mueller, J., Pasquale, D., \& Cruikshank, R. (2011). Adult learners introduced to using mobile technologies in the classroom. Poster presented at Annual Meeting of Canadian Psychological Association, Toronto, Ontario; June 2011.

[15] Freeman, K. (2012). Low income students' test scores leap 30\% with smartphone use.

[16] Sung, Y., Vhang, K., \& Liu, T. (2016). The effects of integrating mobile devices with teaching and learning on students' learning performance: A meta-analysis and research synthesis. Computers \& Education, 94(March 2016), 252-275. https://doi.org/10.1016/j.compedu.2015.11.008

[17] Oostveen, R., Muirhead, W., \& Goodman, W. (2011). Tablet PCs and reconceptualizing learning with technology: a case study in higher education. Interactive Technology and Smart Education, 8(2), 78-93. https://doi.org/10.1108/17415651111141803

[18] Buck, J. L., McInnis, E., \& Casey Randolph, C. (2013). The new frontier of education: The impact of smartphone technology in the classroom. In proceedings of ASEE Southeast Section Conference.

[19] Abugohar, M., Yunus, K., \& Rashid, R. A. (2019). Smartphone applications as a teaching technique for enhancing tertiary learners' speaking skills: Perceptions and Practices. International Journal of Emerging Technologies in Learning, 14(9), 74-92. https://doi.org/10.3991/ijet.v14i09.10375 
[20] Apple. (2015). iPod + iTunes Timeline. https://www.apple.com/pr/products/ipodhistory/

[21] Arar, Y. (2009). From palm pilot to palm pre: A brief history of Palm's handhelds.

[22] Honan, M. (2013). Remembering the Apple Newton's prophetic failure and lasting impact. Retrieved from http://www.wired.com/2013/08/remembering-the-apple-newtonspropheticfailure-and-lasting-ideals/

[23] Microsoft. (2015). History of Microsoft. Retrieved from http://windows.microsoft.com/en$\mathrm{gb} /$ windows/history $-\mathrm{T} 1=$ era 0

[24] Kukulska-Hulme, A., Sharples, M., Milrad, M., Arnedillo-Sánchez, I., \& Vavoula, G. (2009). Innovation in mobile learning: A European perspective. International Journal of Mobile and Blended Learning, 1(1), 13-35.

[25] Quinn, C. (2000). M-learning: Mobile, wireless, in-your-pocket-learning. LineZine: Available at http://www.linezine.com/2.1/features/cqmmwiyp.htm

[26] Attewell, J. (2005). Mobile learning: Reaching hard-to-reach learners and bridging the digital device. In G. Chiazesse, M. Allegra, A. Chifari \& S. Ottaviano (Eds.), Methods and Technologies for learning (pp. 361-365). Southampton: WIT Press.

[27] Kearney, M., Schuck, S., Burden, K. \& Aubusson, P. (2012). Viewing mobile learning from a pedagogical perspective. Research in Learning Technology, 20(1), 1-7. https://doi.org/10.3402/rlt.v20i0/14406

[28] Trifonova, A., \& Ronchetti, M. (2005). Prepare for a bilingual exam with a PDA in your hands. In G. Chiazesse, M. Allegra, A. Chifari \& S. Ottaviano (Eds.), Methods and Technologies for learning (pp. 343-347). Southampton: WIT Press.

[29] Crompton, H. (2013). A historical overview of m-learning. In Z. Berge \& L. Muilenburg (Eds.) Handbook of mobile learning, (pp. 3-14). New York: Routledge.

[30] Bora, K. (2013). Worldwide smartphone sales in Q3 2013: Samsung, Android maintain lead as Apple's market share slips. Retrieved from https:/www.ibtimes.com/worldwidesmartphone-sales-q3-2013-samsung-android-maintain-lead-apples-market-share-1471754

[31] Sergio, F.F. (2012). 10 Ways that mobile learning will revolutionize education. Retrieved from https://www.fastcompany.com/90298467/buying-new-clothes-here-are-3-simpleways-to-shop-more-sustainably

[32] Education.com (2013). Can smartphones make kids smarter? Retrieved from https://www.education.com/magazine/article/smartphones-kids/

[33] Kidzworld. (2011). Top 10 back-to-school smartphone apps. Retrieved from https://www.kidzworld.com/article/25928-top-10-back-to-school-smartphone-apps

[34] Chen, S., Georg, F., \& Loewi, A. (2011). The impact of tablets on information availability. Retrieved from https://cs.stanford.edu/people/eroberts/courses/cs181/projects/201011/TabletDevices/introduction.html

[35] TeachThought Staff. (2017). The 55 best free education apps for iPad. Retrieved from https://www.teachthought.com/technology/the-55-best-best-free-education-apps-for-ipad/

[36] Bojinova, E.D., \& Oigara, J. N. (2011). Teaching and learning with clickers: Are clickers good for students? Interdisciplinary Journal of E-Learning and Learning Objects, 7, 164184.

[37] Johnson, J. T. (2005). Creating learner centered classrooms: Use of an audience response system in pediatric dentistry education. Journal of Dental Education, 69(3), 378-381.

[38] ReaderPen. (2019). Available at http://www.readerpen.com/

[39] International Telecommunications Union. (2019). Key global telecom indicators for the world telecommunication service sector. Retrieved from https://www.itu.int/en/osg/dsg/speeches/Pages/2018-06-06.aspx Accessed June, 2019.

[40] Canalys Estimates. (2012). Smartphones overtake client PCs in 2012. Retrieved from http://www.canalys.com/newsroom/smart-phones-overtake-client-pcs-2011. 
[41] Daanen, H., \& Facer, K. (2007). Opening education 2020 and beyond: Future scenarios for education in the age of new technologies. Retrieved from http://www.nfer.ac.uk/nfer/publications/FUTL54/FUTL54_home.cfm?publicationID=943\&title=2020\%20and $\% 20$ beyond

[42] Boulos, M. N., Wheeler, S., Tavares, C., \& Jones, R. (2011). How smartphones are changing the face of mobile and participatory healthcare: An overview, with example from eCAALYX. Biomedical engineering online, 10(1), 24. https://doi.org/10.1186/1475-925X-10-24

[43] Khaddage, F. (2013). The iPad global embrace! Are we branding mobile learning? In R. McBride \& M. Searson (Eds.), Proceedings of Society for Information Technology \& Teacher Education International Conference 2013 (pp. 3234-3240). Chesapeake, VA: Association for the Advancement of Computing in Education (AACE).

[44] Khaddage, F., Christensen, R., Lai, W., Knezek, G., Norris, C., \& Soloway, E. (2015). A Model driven framework to address challenges in a mobile learning environment. Education and Information Technologies, 20(4), 625-640.

[45] Korf M., \& Oksman, E. (2012). Native, HTML5, or Hybrid: Understanding your mobile application development options. Retrieved from https://developer.salesforce.com/page/Native,_HTML5,_or_Hybrid:_Understanding_Your_Mobile_Application_Development_Opti ons

[46] Mudge, J. T. (2012). Native app vs. Mobile web app: A quick comparison six revisions, useful information for web developers and designers website. Retrieved from http://sixrevisions.com/mobile/native-app-vs-mobile-web-app-comparison/

[47] Robson, R. (2003). Mobile learning and handheld devices in the classroom. Australia: IMS.

[48] Khaddage, F., Knezek, G., \& Baker, R. J. (2012). Formal and informal learning: Bridging the gap via mobile app technology (MAT). In Proceedings of the 15th International Conference on Interactive Collaborative Learning (ICL) (pp.1-3). https://doi.org/10.1109/ICL.2012.6402162

[49] Thomas, M. (2007). E-learning on the move. In Y. E. Shih \& D. Mills (Eds.), Setting the New Standard with Mobile Computing in Online Learning. International Review of Research in Open and distance learning, 8(2), 2007.

[50] Chartrand, R. (2015). Advantages and disadvantages of using mobile devices in a university language classroom. Retrieved from http://www.pcworld.com/article/167231/history_of palm.html - slide1

[51] Carrier, M., \& Nye, A. (2017). Empowering teachers for the digital future. In M. Carrier, R. Damerow \& K. Bailey (Eds.), Digital language learning and teaching: Research, theory, and practice (pp. 208-221). New York, NY: Routledge.

[52] P21 (2019). Framework for 21st Century Learning. The Partnership for 21st Century Skills. Retrieved from http://www.p21.org/about-us/p21-framework

[53] Yusof, N., \& Abugohar, M. A. (2017). Teachers' attitudes towards the use of extracurricular activities in enhancing students' speaking skills. International Journal of Academic Research in Progressive Education and Development, 6(3), 153-163. https://doi.org/10.6007/IJARPED/v6-i3/3168

[54] Abugohar, M. A., Al-Hnifat, M. A., Al-Smadi, O. A., Rashid, R. A., \& Yunus, K. (2019). English language speaking skill issues in an EMP context: Causes and solutions. International Journal of English Linguistics, 9(3), 211-225. https://doi:10.5539/ijel.v9n3p211

[55] Mueller, J., Wood, E., De Pasquale, D., \& Archer, K. (2011). Students learning with mobile technologies in and out of the classroom. In A. Méndez-Vilas (Ed.), Education in a technological world: communicating current and emerging research and technological efforts (pp. 414-420). Spain: Formatex. 
[56] Dede, C. (2010). Comparing frameworks for 21st Century skills. In J. Bellanca \& R. Brandt (Eds.), 21st Century skills: Rethinking how students learn (pp. 51 - 75). Bloomington, IN: Solution Tree Press.

[57] Paris, S., \& Paris, A. (2001). Classroom applications of research on self-regulated learning. Educational Psychologist, 36(2), 89-101.

[58] Pintrich, P. (1995). Current issues in research on self-regulated learning: A discussion with commentaries. Educational Psychologist, 30(4), 171-232.

[59] Zimmerman, B. A. (1989). Social cognitive view of self-regulated academic learning. Journal of Educational Psychology, 81(3), 329-339.

[60] Jacob, S.M., \& B. Issac, B. (2008). Mobile technologies and its impact: An Analysis in higher education. International Journal of Interactive Mobile Technology, 2(1),10-18.

[61] Jacob, S.M., \& B. Issac, B. (2008). The mobile devices and its mobile learning usage analysis. Proceedings of the International Multi Conference of Engineers and Computer Scientists Vol I IMECS 2008, 19-21 March, 2008, Hong Kong.

[62] Tahir, R., \& Arif, F. (2014). Framework for evaluating the usability of mobile educational applications for children. In Proceedings of the Third International Conference on Informatics Engineering and Information Science (ICIEIS2014), At Lodz University of Technology, Lodz, Poland.

[63] Boese, E. (2016). Just-In-Time learning for the just Google it era. In Proceedings of the 47th ACM Technical Symposium on Computing Science Education (pp. 341-345). New York, NY: ACM

[64] McLean, S., Attardi, S. M., Faden, L., \& Goldszmidt, M. (2016). Flipped classrooms and student learning: Not just surface gains. Advances in Physiology Education, 40(1), 47-55.

[65] Tapia-Moreno, F., \& Villa-Martinez, H. (2019). Digital learning tools for mobile devices for accomplish hypothesis testing of statistical parameters. International Journal of Interactive Mobile Technology, 13(6),15-26. https://doi.org/10.3991/ijim.v13i06.10436

[66] Herrington, A., Schrape, J., Flintoff, K., Kelly, J., Singh, K., \& Taylor, D. (2012). PD for ML in HE: Embedding mobile learning in a university context. In T. Amiel \& B. Wilson (Eds.), Proceedings of EdMedia: World Conference on Educational Media and Technology 2012 (pp. 2573-2578). Chesapeake, VA: Association for the Advancement of Computing in Education (AACE).

[67] Herrington, J., Ostashewski, N., Reid, D., \& Flintoff, K. (2014). Mobile technologies in teacher education. In M. Jones \& J. Ryan (Eds.), Successful Teacher Education (pp. 137151). Rotterdam, The Netherlands: Sense Publishers.

[68] Stephens, K. K., \& Pantoja, G. E. (2016). Mobile devices in the classroom: Learning motivations predict specific types of multicommunicating behaviors. Communication Education, 65(4), pp. 463-479.

[69] Khaddage, F., Lanham, E., \& Zhou, W. (2009). A Mobile learning model for universities: Re-blending the current learning environment. International Journal of Interactive Mobile Technologies, 3(1), 18-23.

[70] Kukulska-Hulme, A. (2009). Will mobile learning change language learning? ReCALL, 21(2), 157-165.

[71] Geist, E. (2011). The game changer: Using iPads in college teacher education classes. College Student Journal, 45(4), 758-768.

[72] Miller, W. (2012). iTeaching and learning: Collegiate instruction incorporating mobile tablets. Library Technology Reports (9). Retrieved from http://web.ebscohost.com.ezproxy.stockton.edu:2048/ehost/pdfviewer/pdfviewer?sid=78fc5fe4-4a07-4ff9a1 1 cc $7516 \mathrm{f} 6087 \mathrm{c} 5 \% 40$ sessionmgr $115 \& \mathrm{vid}=4 \&$ hid $=127$ 
[73] Foti, M. K., \& Mendea, J. (2014). Mobile learning: How students use mobile devices to support learning. Journal of Literacy and Technology, 15(3), 58-78.

[74] Arnet, A. (2012). There's an app for that. Retrieved from http://diverseeducation.com/article/17336/

[75] Dias, L., \& Victor, A. (2017). Teaching and learning with mobile devices in the 21st Century digital world: Benefits and challenges. European Journal of Multidisciplinary Studies, 5(2), 339-344.

[76] Eppard, J., Nasser, O., \& Reddy, P. (2016). The Next generation of technology: Mobile apps in the English language classroom. International Journal of Emerging Technologies in Learning, 11(4), 21-27. http://dx.doi.org/10.3991/ijet.v11i04.5293

[77] Harm, N. (2011). Transforming classroom practice with iPad content integration. Webinar given at the Reform Symposium in 2011.

[78] Wishart, j. (2013). Visually dominant, dynamic and yet deceptive: The nature of simulation technology as displayed in secondary school science teaching. In M. P. Clough, J. K. Olson \& D. S. Niederhauser (Eds.), The nature of technology: Implications for learning and teaching (pp. 113-127). Rotterdam, The Netherlands: Sense Publishers.

\section{Authors}

Mohammed Abdulgalil Abugohar is a $\mathrm{PhD}$ student at Universiti Sultan Zainal Abidin (UniSZA), Malaysia. ORCiD: http://orcid.org/0000-0002-0091-9397

Dr. Kamariah Yunus (Associate Professor) is the Deputy Dean (Academic \& Graduate) in the Faculty of Languages and Communication, Universiti Sultan Zainal Abidin (UniSZA), 21300 Kuala Nerus, Terengganu, Malaysia.

ORCiD: http://orcid.org/0000-0002-7103-6911

Dr. Ghaleb Rabab'ah (Professor) is a full professor of linguistics in the Dept. of English Language and Literature at the University of Jordan. He published many papers in Linguistics, Applied Linguistics and ESL in international journals, such as Journal of Pragmatics, Poznan Studies in Contemporary Linguistics, Journal of Psycholinguistic Research, and Babel. ORCiD: https://orcid.org/0000-0003-1804-5859

Dr. Tarig Awad Eltahir Ahmed (Assistant Professor) is with the Faculty of Education, Alzaiem Alazhari University, Khartoum, Sudan. His research interests include, among others, syntax and morphology.

Article submitted 2019-05-01. Resubmitted 2019-06-12. Final acceptance 2019-07-03. Final version published as submitted by the authors. 